\title{
Bacterial Blight in Carrot Seed Crops in the Pacific Northwest
}

\author{
Lindsey J. du Toit, Vegetable Seed Pathologist, Washington State University (WSU)-NWREC, Mount Vernon \\ 98273; Fred J. Crowe, Plant Pathologist, Oregon State University (OSU)-COARC, Madras 97741; Mike L. Derie, \\ Agricultural Research Technologist, WSU-NWREC, Mount Vernon 98273; Rhonda B. Simmons, Agricultural Re- \\ search Technologist, OSU-COARC, Madras 97741; and Gary Q. Pelter, WSU Extension Educator, Grant/Adams \\ Counties, Ephrata 98823
}

\begin{abstract}
du Toit, L. J., Crowe, F. J., Derie, M. L., Simmons, R. B., and Pelter, G. Q. 2005. Bacterial blight in carrot seed crops in the Pacific Northwest. Plant Dis. 89:896-907.

Carrot (Daucus carota subsp. sativus) seed crops in Oregon and Washington were surveyed in 2001-02 and 2002-03 for development of Xanthomonas campestris pv. carotae, causal agent of bacterial blight. For each state and season, 20 plants were sampled from each of 7 to 12 directseeded crops twice in the fall or winter and three times from spring to summer; and from each of 2 to 4 steckling (root-to-seed) crops three times from spring to summer. X. campestris pv. carotae was detected in 1 of 15 and 6 of 32 stock seed lots planted in the fall in Oregon and Washington, respectively, and in 2 of 6 steckling shipments planted in each state in the spring. The pathogen was detected at $10^{2}$ to $10^{8} \mathrm{CFU} / \mathrm{g}$ foliage in 1 of 22 and 10 of 14 direct-seeded crops within 2 months of planting in 2001 and 2002, respectively. The prevalence of X. campestris pv. carotae then increased through the season in most seed crops, although bacterial blight symptoms were not observed until April in Oregon and July in Washington in both seasons. In August 2002 and 2003, X. campestris pv. carotae was detected in all 10 and 13 crops surveyed in Oregon, respectively; and in 11 of 12 and 7 of 10 crops in Washington, respectively. The pathogen was typically less prevalent in steckling versus direct-seeded crops. X. campestris pv. carotae was detected in 20 of 22 and 19 of 23 harvested seed lots in Oregon and Washington, respectively, at populations ranging from $1.3 \times 10^{1}$ to $1.4 \times 10^{8} \mathrm{CFU} / \mathrm{g}$ seed. Airborne $X$. campestris $\mathrm{pv}$. carotae, detected $\leq 1,600 \mathrm{~m}$ downwind of crops being threshed in Oregon in September of 2003 and 2004, may provide a source of inoculum for newly planted seed crops between overlapping biennial seasons for carrot seed production. Despite the prevalence of this pathogen in the Pacific Northwest, carrot seed lots free of $X$. campestris pv. carotae were detected, demonstrating the ability to produce clean seed in this region by adhering to recommended practices for management of bacterial blight.
\end{abstract}

Additional keywords: Apiaceae, umbelliferous

Carrot (Daucus carota L. subsp. sativus (Hoffm.) Arcang.) seed crops in central Washington and central Oregon produce up to $75 \%$ of the U.S. supply and up to $50 \%$ of the world supply of carrot seed (29) on 800 to 1,200 hectares per state $(10,19)$. Carrot seed crops may be produced as direct-seeded or steckling (rootto-seed) crops (22). In the Pacific Northwest region of the United States (Idaho, Oregon, and Washington), direct-seeded crops are typically planted in August to early September (11). Bolting (conversion from vegetative to reproductive growth) of the plants is initiated the following spring

Corresponding author: L. J. du Toit

E-mail: dutoit@wsu.edu

* The $\boldsymbol{e}$-Xtra logo stands for "electronic extra" and indicates that Figures 1 and 2 appear in color in the online edition.

Accepted for publication 27 April 2005

DOI: 10.1094/PD-89-0896

(C) 2005 The American Phytopathological Society after the plants have vernalized as a result of exposure to winter conditions (22). For most steckling seed crops grown in the Pacific Northwest, seed of the parent lines of hybrid cultivars are planted in raised beds in middle to late September, usually in the Imperial Valley, CA, or near Yuma, AZ. The roots are dug in January or February and stored at 1 to $2^{\circ} \mathrm{C}$ for 4 to 8 weeks depending on the cultivar, type of carrot, and growing conditions. The vernalized roots are then transported to the Pacific Northwest, where they are transplanted manually $(22,25)$. Direct-seeded and steckling seed crops are cut, windrowed, and dried in the fields for 10 to 14 days in August or September. The crops are then threshed and the seed is sent to conditioning plants for cleaning and sizing (25).

As a seedborne pathogen, Xanthomonas campestris pv. carotae, causal agent of bacterial blight of carrot (13), is a concern to carrot growers in many regions of the world $(8,15,17,18,23,33)$ and to the carrot seed industry in the Pacific Northwest $(5,6)$. Infections can occur on roots, foliage, stems, umbels, and seed $(1,8,13,20)$.
Leaf symptoms start as small, irregular, chlorotic areas and expand to water-soaked lesions that may become a greasy greenblack color or a tan color as they dry, typically surrounded by an irregular yellow halo. Dark brown, linear lesions form on stems and petioles, and a gummy bacterial exudate may develop. If flowers on a seed plant are infected early in development, entire umbels may be blighted with no seed produced. Infections of more mature umbels result in partial blighting (Fig. 1) $(8,13)$. Seed yield may then be affected, and seed may be infected internally or contaminated on the surface $(1,31)$. Infection of seed by $X$. campestris pv. carotae can reduce germination, resulting in significant losses to seed growers (1). As a consequence, seed companies face expenses associated with treating infected seed lots, and infected seed lots may be rejected from some markets $(8,17)$.

Cultivated carrot is the primary host of $X$. campestris pv. carotae, although the pathogen has been reported to infect a number of other umbelliferous plant species $(8,21)$. The bacterium can survive on or in carrot seed, and is spread through the movement of infested or infected seed. $X$. campestris pv. carotae persists in infected carrot residues in the soil for up to a year (8). Within crops, splashing water, insects, and machinery are the primary documented means of dispersal of $X$. campestris pv. carotae (8). The presence of water is necessary for infection to occur, with the pathogen reproducing most rapidly under warm $\left(25\right.$ to $\left.30^{\circ} \mathrm{C}\right)$ and wet conditions $(13,20)$. Under such conditions, symptoms appear within 10 to 12 days of infection, and the disease progresses rapidly $(8,13)$.

Planting healthy seed or treated seed is important in the management of bacterial blight $(8,17,31)$. Other management recommendations include 2- to 3-year crop rotations, incorporating residues into the soil promptly after harvest, avoiding overhead irrigation that promotes dispersal of the bacterium and creates favorable conditions for infection, and applications of copper bactericides (8). Seed can be disinfected by hot water treatment $\left(52^{\circ} \mathrm{C}\right.$ for up to $25 \mathrm{~min})(1,8)$. Limited resistance to bacterial leaf blight is available in some commercial cultivars (20).

Bacterial blight continues to cause losses to the carrot industry despite the 
ability to detect infected seed lots $(14,15,17,30)$, availability of treatments to eliminate seedborne inoculum $(1,8)$, and adherence to seed contamination thresholds developed for some regions of carrot production (31). Losses may occur when growers do not adhere to all of the recommended management practices. In the semi-arid Pacific Northwest, overhead irrigation systems are less labor-intensive and therefore less expensive than furrow or drip irrigation systems $(11,34)$. Some fields are not suited topographically for furrow irrigation. As a result, approximately $50 \%$ of the carrot seed crops in this region are produced using overhead irrigation (10), which favors development of bacterial blight. The intensive global nature of the seed industry, in which stock seed lots are often produced in different countries from where the seed crops are grown, sometimes results in inadequate time for stock seed lots to be treated for seedborne pathogens before the deadlines for planting biennial seed crops. Strandberg and White (28) reported that growers and seed producers are sometimes reluctant to use hot water seed treatments because of reports of seed damage from such treatment. In addition, symptoms of bacterial blight typically do not develop on infected carrot plants until epiphytic populations of $X$. campestris pv. carotae reach $>10^{6} \mathrm{CFU} / \mathrm{g}$ (8). Timing bactericide applications based on initial appearance of symptoms of bacterial blight may be too late for effective control of this pathogen in the 14- to 15-month biennial season for carrot seed crops.

Empirical evidence suggests bacterial blight is more prevalent in carrot seed crops grown in central Oregon than in central Washington, despite similarities in climatic conditions and cropping practices between these two semi-arid regions $(5,6)$. To our knowledge, limited research has been carried out on the epidemiological nature of bacterial blight in the biennial system of carrot seed production in this semi-arid region. The objectives of this project were to: (i) identify primary sources of inoculum associated with bacterial blight in carrot seed crops in central Oregon and central Washington, and (ii) assess the nature of development of $X$. campestris pv. carotae in the biennial system of carrot seed production. Information generated from this study may help develop more effective integrated management programs for bacterial blight in carrot seed crops. Preliminary results have been presented $(5,6)$.

\section{MATERIALS AND METHODS}

2001-02 survey. To monitor development of $X$. campestris pv. carotae through the 2001-02 season under the diversity of production practices and the range of locations of carrot seed production in the $\mathrm{Pa}-$ cific Northwest, 10 direct-seeded carrot seed crops (fields OR1 to OR10) and four steckling crops (OR11 to OR14) were surveyed in central Oregon, and 12 directseeded crops (WA1 to WA12) and two steckling crops (WA13 and WA14) were surveyed in central Washington (Table 1). Direct-seeded crops were sampled twice in the fall or winter of 2001-02: (i) from 2 to 10 October 2001 in Oregon, and on 28 September and 5 October 2001 in Washington (before fall frosts); and (ii) 6 to 8 November 2001 in Oregon, and on 30 November 2001 or 16 January 2002 in Washington (after the onset of fall frosts). Snow cover in Washington necessitated a delay in sampling some fields until January 2002. At each sampling date, 20 plants were collected from each field in a "W"pattern. People collecting the plants surface-sterilized their hands with $70 \%$ ethyl alcohol between samples. Each plant was placed in a separate plastic bag and stored in a cooler with ice for transportation to a refrigerated facility $\left(4\right.$ to $\left.8^{\circ} \mathrm{C}\right)$.

For the steckling seed crops in fields OR11 to OR14, WA13, and WA14 (Table 1), roots were sampled in April 2002 directly from the crates in which they had been shipped. In addition, from 1 to 9 April 2002 in Oregon and from 28 March to 11 April 2002 in Washington (early spring), 20 plants were sampled from the direct-seeded fields as described for the fall samples. Fields OR3, OR4, WA1, and WA8 were dropped from the survey prior to this sampling period because the crops were removed by the growers or seed companies. Similarly, field OR11 was dropped from the survey after samples were collected in April 2002.

Plant samples $(n=20)$ were collected again from each field from 4 to 10 June 2002 in Oregon, and on 3 or 10 June 2002 in Washington (late spring), as described above. The canopies of the open pollinated crops were too dense to walk between rows, so samples were collected within 3 to $6 \mathrm{~m}$ of the perimeter at each of $20 \mathrm{sam}$ pling locations per field in Washington. For hybrid seed crops, samples were collected approximately $3 \mathrm{~m}$ within the crop from the location of wheel-lines, irrigation pipes, or alleys between the male and female rows. In both states, whole plants were sampled or, for plants $>75 \mathrm{~cm}$ tall, leaves (three to four per plant), stems (two to three $15-\mathrm{cm}$ sections per plant), and umbels (three or four per plant) were sampled. Field OR10 was dropped from the survey after samples were collected in June. A final set of plants $(n=20)$ was sampled from each field from 15 to 24 August 2002 in Oregon, and on 22 or 30 July 2002 in Washington (late summer), as described for samples collected in June. The seed crops were swathed, windrowed, and harvested by the seed growers or seed companies in August or September 2002.

2002-03 survey. The survey was repeated in 2002-03, with eight directseeded crops (fields WA15 to WA22) and four steckling crops (WA23 to WA26) sampled in Washington, and seven directseeded (OR15 to OR21) and seven steckling (OR23 to OR28) crops sampled in Oregon (Table 1). Samples were collected from each Washington crop at five sampling periods: 7 to 8 October 2002 (prior to fall frosts), 8 November 2002 (after the onset of fall frosts), 26 March to 23 April 2003 (early spring), 2 to 12 June 2003 (late spring), and 28 July to 4 August 2003 (late summer). Fields WA18 and WA17 were dropped from the survey after the first and second sampling periods, respectively; and field WA22 was added at the second sam-



Fig. 1. Umbel blight of carrot caused by Xanthomonas campestris pv. carotae. 
Table 1. Carrot seed crops monitored for Xanthomonas campestris pv. carotae in 2001-02 and 200203 in central Oregon and central Washington

\begin{tabular}{|c|c|c|c|c|}
\hline $\begin{array}{l}\text { Season, state } \\
\text { Field code }\end{array}$ & Type of carrot ${ }^{a}$ & $\begin{array}{l}\text { Hybrid or } \\
\text { open pollinated }\end{array}$ & $\begin{array}{l}\text { Direct-seeded } \\
\text { or stecklingb }\end{array}$ & $\begin{array}{l}\text { Irrigation } \\
\text { system }^{c}\end{array}$ \\
\hline \multicolumn{5}{|c|}{ 2001-02 Oregon } \\
\hline OR1 & Nantes & Hybrid & Direct-seeded & $\begin{array}{l}\text { Overhead (fall); } \\
\text { furrow (spring) }\end{array}$ \\
\hline OR2 & Nantes & Hybrid & Direct-seeded & Furrow \\
\hline OR3 & Nantes $\times$ Amsterdam & Hybrid & Direct-seeded & Furrow \\
\hline OR4 & Nantes & Hybrid & Direct-seeded & Furrow \\
\hline OR5 & Nantes & Hybrid & Direct-seeded & Overhead \\
\hline OR6 & Nantes & Hybrid & Direct-seeded & Overhead \\
\hline OR7 & Nantes & Hybrid & Direct-seeded & Overhead \\
\hline OR8 & Nantes & Hybrid & Direct-seeded & Overhead \\
\hline OR9 & Nantes & Hybrid & Direct-seeded & Overhead \\
\hline OR10 & Nantes $\times$ Amsterdam & Hybrid & Direct-seeded & $\begin{array}{l}\text { Overhead (fall); } \\
\text { furrow (spring) }\end{array}$ \\
\hline OR11 & Imperator & Hybrid & Steckling & Overhead \\
\hline OR12 & Imperator & Hybrid & Steckling & Overhead \\
\hline OR13 & Imperator & Hybrid & Steckling & Overhead \\
\hline OR14 & Imperator & Hybrid & Steckling & Furrow \\
\hline \multicolumn{5}{|c|}{ 2001-02 Washington } \\
\hline WA1 & Kuroda & Open pollinated & Direct-seeded & Overhead \\
\hline WA2 & Nantes & Hybrid & Direct-seeded & Furrow \\
\hline WA3 & Nantes & Hybrid & Direct-seeded & Overhead \\
\hline WA4 & Nantes $\times$ Flakkee & Hybrid & Direct-seeded & Furrow \\
\hline WA5 & Amsterdam & Open pollinated & Direct-seeded & Overhead \\
\hline WA6 & Chantenay & Open pollinated & Direct-seeded & Furrow \\
\hline WA7 & Flakkee & Open pollinated & Direct-seeded & Furrow \\
\hline WA8 & Chantenay & Open pollinated & Direct-seeded & Furrow \\
\hline WA9 & Nantes & Open pollinated & Direct-seeded & Furrow \\
\hline WA10 & Imperator & Hybrid & Direct-seeded & $\begin{array}{l}\text { Overhead (fall); } \\
\text { drip (spring) }\end{array}$ \\
\hline WA11 & - & Hybrid & Direct-seeded & Overhead \\
\hline WA12 & Chantenay & Open pollinated & Direct-seeded & Furrow \\
\hline WA13 & Nantes $\times$ Amsterdam & Hybrid & Steckling & Furrow \\
\hline WA14 & Imperator & Hybrid & Steckling & Overhead \\
\hline \multicolumn{5}{|c|}{ 2002-03 Oregon } \\
\hline OR15 & Nantes & Hybrid & Direct-seeded & Overhead \\
\hline OR16 & Nantes & Hybrid & Direct-seeded & Furrow \\
\hline OR17 & Nantes & Hybrid & Direct-seeded & Overhead \\
\hline OR18 & Nantes & Hybrid & Direct-seeded & Overhead \\
\hline OR19 & Nantes & Hybrid & Direct-seeded & Overhead \\
\hline OR20 & - & Hybrid & Direct-seeded & Overhead \\
\hline OR21 & Nantes & Hybrid & Direct-seeded & Overhead \\
\hline OR22 & Nantes & Hybrid & Direct-seeded & Overhead \\
\hline OR23 & Imperator & Hybrid & Direct-seeded & Furrow \\
\hline OR24 & Imperator & Hybrid & Direct-seeded & Overhead \\
\hline OR25 & Nantes & Hybrid & Steckling & Overhead \\
\hline OR26 & Imperator & Hybrid & Steckling & Overhead \\
\hline OR27 & Nantes & Hybrid & Steckling & Overhead \\
\hline OR28 & Imperator & Hybrid & Steckling & Overhead \\
\hline \multicolumn{5}{|c|}{ 2002-03 Washington } \\
\hline WA15 & Chantenay & Open pollinated & Direct-seeded & Furrow \\
\hline WA16 & Nantes & Hybrid & Direct-seeded & Overhead \\
\hline WA17 & - & Hybrid & Direct-seeded & Overhead \\
\hline WA18 & Laval & Open pollinated & Direct-seeded & $\begin{array}{l}\text { Furrow (fall); } \\
\text { drip (spring) }\end{array}$ \\
\hline WA19 & Chantenay & Open pollinated & Direct-seeded & Furrow \\
\hline WA20 & Chantenay & Open pollinated & Direct-seeded & Furrow \\
\hline WA21 & Flakkee $\times$ Flakkee & Hybrid & Direct-seeded & Overhead \\
\hline WA22 & Imperator & Hybrid & Direct-seeded & Furrow \\
\hline WA23 & Imperator & Hybrid & Steckling & Overhead \\
\hline WA24 & Imperator & Hybrid & Steckling & Furrow \\
\hline WA25 & Nantes $\times$ Flakkee & Hybrid & Steckling & Overhead \\
\hline WA26 & Imperator & Hybrid & Steckling & Drip \\
\hline
\end{tabular}

a Type of carrot as determined by root shape, rate of growth, and intended market (22). - = information not provided by seed company.

${ }^{\mathrm{b}}$ During each biennial season, direct-seeded crops were planted in Oregon in early to mid-August, and in Washington between late August and early September. Stecklings for root-to-seed crops were grown in Imperial Valley, CA, or Yuma, AZ, from September through January, placed in cold storage for 6 to 8 weeks, then transported to Oregon or Washington and transplanted from March through April.

${ }^{\mathrm{c}}$ Overhead $=$ sprinkler irrigation system, e.g., center pivot, wheel-line, or solid-set. pling period at the request of the seed company. For steckling crops, plants were sampled directly from the shipping crates prior to transplanting in April 2003. In Oregon, samples were collected at five sampling periods: 4 to 10 October 2002 (prior to fall frosts), 13 November 2002 (after the onset of fall frosts), 31 March to 17 April 2003 (early spring), 10 to 23 June 2003 (late spring), and 1 to 15 August 2003 (late summer). Field OR18 was dropped from the survey after the second sampling period; and steckling crops OR27 and OR28 were added in June 2003. In both states, samples were collected as described for the 2001-02 survey.

Plant assays. Plant samples were assayed for $X$. campestris pv. carotae within 2 to $14 \mathrm{~h}$ of sampling in Oregon, and within 24 to $36 \mathrm{~h}$ of sampling in Washington. Plants sampled in Oregon were assayed at the Oregon State UniversityCentral Oregon Agricultural Research Center (OSU-COARC); plants sampled in Washington were assayed at the Washington State University-Northwestern Washington Research \& Extension Center (WSU-NWREC). After completing the assays, dry weights were determined by drying the samples for 12 to $36 \mathrm{~h}$ at 65 to $70^{\circ} \mathrm{C}$. For the first two sampling periods of each season, the total foliage of each plant was used for the assays, except for plants collected from field WA7, from which a subsample of $3 \mathrm{~g}$ (fresh weight) of the foliage of each plant was assayed because of the large size of these plants relative to those of the other fields sampled in fall 2002. For the third, fourth, and fifth sampling periods, a sample of up to $50 \mathrm{~g}$ (fresh weight) of leaves, umbels, and stems was assayed per plant.

Carrot foliage was assayed for $X$. campestris pv. carotae using the protocol described by Umesh et al. (31), with slight modifications. In Washington, foliage from each plant was cut into 1- to 4-mm pieces, placed in a $125-\mathrm{ml}$ Erlenmeyer flask containing $30 \mathrm{ml}$ of cold $\left(4\right.$ to $\left.8^{\circ} \mathrm{C}\right)$ sterile phosphate buffer $\left(12.5 \mathrm{mM} \mathrm{PO}_{4}, \mathrm{pH} 7.1\right)$, swirled on a rotary shaker for $60 \mathrm{~min}$, and the suspension concentrated 10 -fold by centrifugation at $10,000 \times g$ for $10 \mathrm{~min}$. The concentrate was assayed for $X$. campestris pv. carotae by: (i) plating a dilution series (three replications of a 0.1$\mathrm{ml}$ aliquot per dilution) onto XCS agar, a semi-selective medium for $X$. campestris pv. carotae (35); and (ii) a polymerase chain reaction (PCR) assay using a $3 \mathrm{~S}$ primer pair specific for $X$. campestris pv. carotae that directed amplification of a 350-bp target fragment of genomic DNA as described by Umesh et al. (30) and Meng et al. (17). For the PCR assay, DNA was extracted using the CTAB method (36) for samples collected in October 2001, and using the Dellaporta method (4) for samples collected in November 2001 and January 2002. Direct PCR assays of the 
sample washes were not carried out for subsequent samples, as the plating assay proved more sensitive than the PCR assay and enabled the bacterial population to be quantified. For the third, fourth, and fifth sampling periods of each season, the volume of buffer used for extraction was increased up to $250 \mathrm{ml}$ per sample and the washes carried out in 500-ml Erlenmeyer flasks. The centrifugation step was eliminated for the fourth and fifth sampling periods each season.

In Oregon, foliage of each sample was cut into pieces, placed in a flask containing filtered deionized water $(50,100$, or 150 $\mathrm{ml}$ depending on the amount of foliage), swirled on a rotary shaker for $15 \mathrm{~min}$ at $250 \mathrm{rpm}$, and a dilution series plated onto XCS agar (three replications of $0.2 \mathrm{ml}$ per dilution). For subsequent sampling periods in Oregon, foliage washes were carried out on a rotary shaker for $60 \mathrm{~min}$ using sterile buffer, as described for samples processed in Washington.

The XCS agar plates were incubated in the dark at $28^{\circ} \mathrm{C}$ for 6 to 8 days, and colonies typical of $X$. campestris pv. carotae were enumerated. Representative colonies from each field were transferred to yeast dextrose carbonate (YDC) agar (24) for verification of colony morphology. A random sample of colonies from each field was then tested using the PCR assay described by Umesh et al. (30) and Meng et al. (17). PCR assays were carried out at the WSU-NWREC. Populations of the pathogen detected on each plant were calculated as CFU per gram of tissue (dry weight). The mean population of $X$. campestris pv. carotae detected in each field at each sampling period was calculated as the mean $\log (\mathrm{CFU} / \mathrm{g}$ tissue $)$ of those plants that tested positive for the pathogen.

Seed assays. Where available, samples of stock seed (seed of the parent lines used to plant a seed crop) for each field surveyed were collected from seed companies, and two to three 10-g (approximately 5,000 seed) subsamples of each seed lot were assayed for $X$. campestris pv. carotae using a seed wash and dilution plating protocol on XCS agar medium as described by Kuan et al. (15) and Umesh et al. (31). Each seed sample was soaked overnight at $4^{\circ} \mathrm{C}$ in $100 \mathrm{ml}$ of saline $(0.85 \% \mathrm{NaCl})$. Two drops of Tween 20 were then added to each flask, which was placed on a rotary shaker for $5 \mathrm{~min}$. The seed soak was then filtered through cheesecloth to remove the seed, and a dilution series of the wash was plated onto XCS agar medium (0.1-ml aliquot onto each of three replicate plates per dilution). Stock seed lots from Washington fields for the 2001-02 survey were also tested twice by direct PCR assay of the seed wash.

Three 10-g samples of seed harvested from each crop in 2002 and 2003 were supplied by the seed companies and assayed for $X$. campestris pv. carotae using the seed wash and dilution plating protocol described by Umesh et al. (31). A sample of colonies resembling $X$. campestris on XCS agar was transferred to YDC agar for each seed lot. Colonies resembling $X$. campestris pv. carotae on both agar media were enumerated, and the mean population of the bacterium per seed lot was calculated as the mean $\log (\mathrm{CFU} / \mathrm{g}$ seed $)$ for each sample per seed lot.

Pathogenicity tests. For each sampling period and each seed assay, representative colonies ( $n=1$ to 3 per field or seed lot) resembling $X$. campestris pv. carotae on XCS and YDC agars, and for which a 350bp fragment of genomic DNA was amplified using the PCR assay and $3 \mathrm{~S}$ primer pair described above, were tested for pathogenicity on carrot seedlings in the greenhouse. A suspension of approximately $10^{8} \mathrm{CFU} / \mathrm{ml}$ of each isolate was prepared from an 18- to 20 -h shake culture in medium 523 (12) and atomized onto the leaves of three or five 6- to 10 -week-old seedlings (approximately $10 \mathrm{ml}$ per plant) of the carrot cultivar Red Core Chantenay using an airbrush (Braun-Knecht-Heimann, San Francisco, CA) operated at 12 psi. Inoculated plants were enclosed in clear plastic bags for 3 days in the greenhouse and monitored for up to 6 weeks for symptoms of bacterial blight. A known pathogenic isolate of $X$. campestris pv. carotae and a noninoculated control treatment were included in the pathogenicity tests for each sampling period and for seed assays.

Sampling of dust and debris during threshing of carrot seed crops. A Thermo Andersen Two Stage Viable Impactor (Thermo MIE, Bedford, MA) was used to determine whether dust and debris generated during the threshing of carrot seed crops (Fig. 2) could generate windborne $X$. campestris pv. carotae that might serve as a source of inoculum for newly emerged

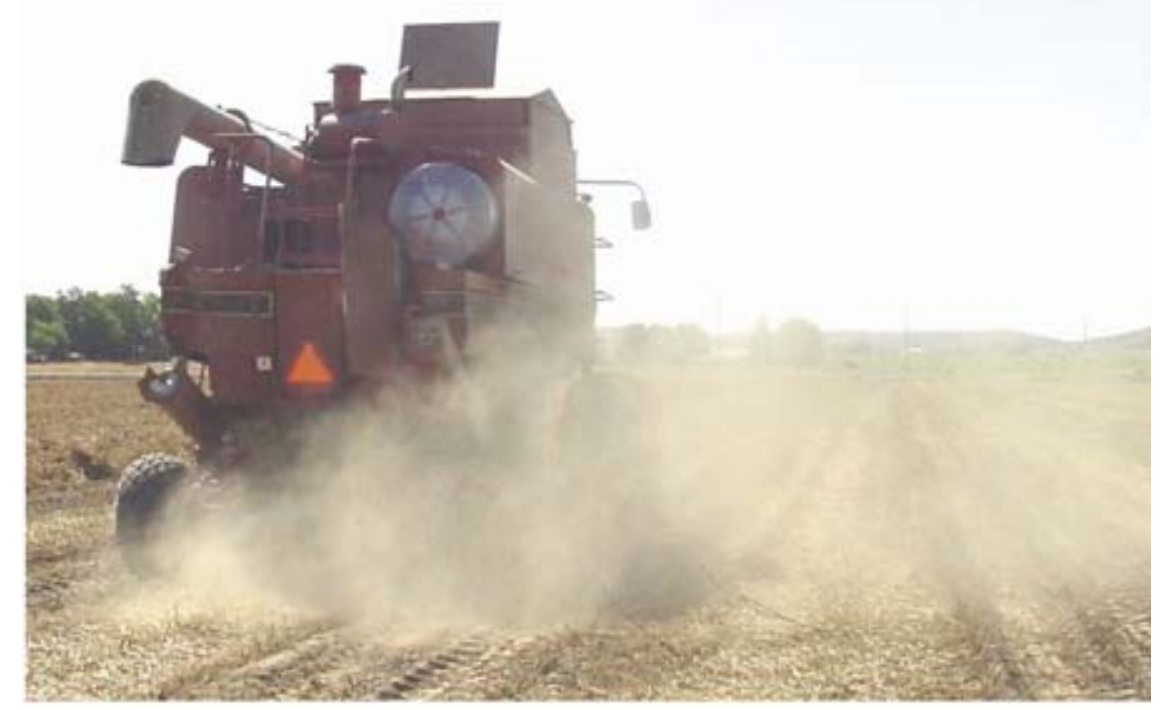

Fig. 2. Carrot seed thresher generating aerosolized debris in which Xanthomonas campestris pv. carotae, causal agent of bacterial blight of carrot, was detected. carrot seedlings in direct-seeded crops planted nearby for the subsequent cropping season. The air sampler was powered by a generator (Homelite Model 4400, Port Chester, NY) and placed on the back of a pickup truck. The truck was driven downwind of a thresher in operation at a similar speed, approximately 5 to $10 \mathrm{~km} / \mathrm{h}$, in order to maintain a constant distance of separation for sampling. Sampling was carried out at several distances from the thresher, ranging from approximately 10 to $1,600 \mathrm{~m}$, at each of four locations in Oregon in September 2002 and three locations in September 2003 (Table 2). To trap airborne $X$. campestris pv. carotae, two petri plates with XCS agar medium were placed in the air sampler at each sampling for durations ranging from $1 \mathrm{~s}$ to $15 \mathrm{~min}$. Sampling time was increased with sampling distance. A hand-held anemometer and direction during each sampling period.

Sampling of honey bees. To determine whether honey bees, which are typically used as pollinators for carrot seed crops in the Pacific Northwest, may serve as vectors of $X$. campestris pv. carotae, bees were collected from four locations at the edge of field WA15 on 15 July 2003. Field WA15 was selected because the crop in this field had the highest incidence of plants infected with $X$. campestris pv. carotae in Washington during the June 2003 sampling period. To catch each honey bee, a 50-ml centrifuge tube was inverted over the bee as it foraged on umbels. Five bees were placed in each of 22 centrifuge tubes (total of 110 bees), and $30 \mathrm{ml}$ of sterile phosphate buffer was added to each tube. The bees were stored overnight in a cooler with ice. The contents of each centrifuge tube were then poured through a double layer of cheesecloth to remove the bees. The bee wash was centrifuged at $10,000 \times$ was used to record the average wind speed 
$g$ for $10 \mathrm{~min}$, the supernatant poured off, and the pellet resuspended in $3 \mathrm{ml}$ of sterile phosphate buffer. A dilution series $(0$, $10^{-1}$, and $10^{-2}$ ) was then prepared, and a $0.1-\mathrm{ml}$ aliquot of each dilution was spread onto each of three plates of XCS agar, as described for the foliar and seed washes. The plates were incubated at $28^{\circ} \mathrm{C}$ for 6 to 7 days, and colonies resembling $X$. campestris pv. carotae were enumerated.

Honey bees were collected again in July located near Yakima, WA, which displayed a low incidence of bacterial blight symptoms $(<2 \%$ of the plants). Bees were also collected in August 2004 from two hybrid seed crops in Oregon, one near Madras with a moderately high incidence of bacterial blight ( 20 to $25 \%$ of the plants symptomatic) and one near Culver with a moderate incidence of bacterial blight (5 to $10 \%$ of the plants symptomatic). For each of these 2004 fields, $30 \mathrm{ml}$ of phosphate buffer was placed in each of 21 centrifuge tubes containing five bees.

To test for the presence of inhibitors on honey bees that might interfere with detection of $X$. campestris pv. carotae, a known pathogenic isolate of $X$. campestris pv. carotae was added to one of the 21 tubes CFU from an overnight broth culture grown in medium 523). The bacteria were added to the tube about $90 \mathrm{~min}$ prior to pouring the bee wash through cheesecloth. In addition, the known pathogenic isolate 2004 from an open pollinated seed crop containing bees (approximately $5 \times 10^{4}$

of the pathogen was added at the same rate to a test tube containing $30 \mathrm{ml}$ of phosphate buffer only (no bees). The samples were processed as described for bees collected in 2003.

Environmental conditions and cultural practices. Information on production practices associated with seed crops sampled in this survey was requested from growers, seed companies, and state extension resources (11). Regional weather data (minimum, maximum, and average daily temperatures; heat units calculated as the sum of [average daily temperature $-10^{\circ} \mathrm{C}$ ]; and total daily precipitation) were collected from the Bureau of Reclamation AgriMet weather station at the OSUCOARC in Madras, OR, and from the WSU Public Agricultural Weather Station (PAWS) for Moses Lake, WA, from $1 \mathrm{Au}-$ gust 2001 through 30 September 2003.

\section{RESULTS}

2001-02 survey. The 10 direct-seeded carrot seed crops surveyed in central Oregon were planted between 1 August and 19 August 2001, and the 12 direct-seeded crops sampled in central Washington were planted 3 to 5 weeks later, between 20 August and 5 September 2001 (Table 1). Symptoms of bacterial blight were not observed on any of the plants sampled during the first (pre-frost) sampling period, and $X$. campestris pv. carotae was isolated from only one plant in one field in Oregon (the overhead irrigated crop in field OR5)

Table 2. Population of Xanthomonas campestris pv. carotae detected in airborne dust and debris sampled downwind of seed threshers operating in carrot seed crops in central Oregon in September 2002 and September 2003

\begin{tabular}{|c|c|c|c|c|}
\hline $\begin{array}{r}\text { Date } \\
\text { Site }\end{array}$ & $\begin{array}{l}\text { Est. distance (m) } \\
\text { from seed thresher }\end{array}$ & $\begin{array}{l}\text { No. of air } \\
\text { samples }\end{array}$ & $\begin{array}{l}\text { Mean } \pm \text { SD of } \\
\text { CFU/liter air }\end{array}$ & CFU/g seed \\
\hline \multicolumn{5}{|c|}{ September 2002} \\
\hline \multirow[t]{3}{*}{1} & 30 & 10 & $377 \pm 530$ & - \\
\hline & 45 & 7 & $954 \pm 1,223$ & \\
\hline & 75 & 3 & $51 \pm 37$ & \\
\hline \multirow[t]{6}{*}{2} & 7 & 4 & $425 \pm 850$ & $3.8 \times 10^{5}$ \\
\hline & 30 & 12 & $294 \pm 977$ & \\
\hline & 45 & 1 & 0 & \\
\hline & 60 & 8 & $34 \pm 28$ & \\
\hline & 90 & 1 & 0 & \\
\hline & 250 & 3 & 0 & \\
\hline 3 & 275 & 8 & 0 & $9.9 \times 10^{7}$ \\
\hline $4^{\mathrm{d}}$ & 1,600 & 5 & $1 \pm 1$ & $2.6 \times 10^{5}$ \\
\hline \multicolumn{5}{|c|}{ September 2003} \\
\hline \multirow[t]{2}{*}{5} & 30 & 10 & $23 \pm 29$ & - \\
\hline & 500 & 2 & $3 \pm 1$ & \\
\hline \multirow[t]{3}{*}{6} & 30 & 4 & $17 \pm 8$ & - \\
\hline & 50 & 4 & $9 \pm 4$ & \\
\hline & 400 & 2 & $85 \pm 120$ & \\
\hline $4^{\mathrm{d}}$ & 1,600 & 4 & $1 \pm 1$ & - \\
\hline
\end{tabular}

a At each location, a Thermo Andersen Two Stage Viable Impactor (Thermo MIE, Bedford, MA) was placed on the back of a pickup truck driven the estimated distance downwind of a carrot seed thresher in operation. The duration of sampling ranged from $1 \mathrm{~s}$ to $15 \mathrm{~min}$.

${ }^{\mathrm{b}}$ Mean population of $X$. campestris pv. carotae detected (CFU/liter air) on XCS agar (35) in two petri plates placed in the Anderson Impactor for each sampling period.

${ }^{c}$ Population of $X$. campestris pv. carotae detected on $10 \mathrm{~g}$ of the harvested seed sampled from the crop being threshed at the site. A seed wash and dilution plating protocol was used as described by Umesh et al. (31). $-=$ seed not available to assay.

${ }^{\mathrm{d}}$ In both seasons, site 4 was also located within 2.5 to $8.0 \mathrm{~km}$ of at least five other seed crops being threshed.
(Fig. 3A), at a mean population of $1 \times 10^{5}$ CFU/g tissue (Fig. 4A). The pathogen was not detected on any of the plants sampled in Washington prior to the start of fall frosts (Fig. 3B and 4B).

$X$. campestris pv. carotae was detected in 8 of 10 crops sampled in central Oregon in November after the first fall frosts (Fig. $3 \mathrm{~A}$ ), including both overhead and furrow irrigated fields, although crops were still symptomless for bacterial blight. The incidence of plants that tested positive for $X$. campestris pv. carotae in these crops ranged from 2 out of 20 (10\% in the overhead irrigated crop in field OR6) to 9 out of 20 (45\% in the overhead irrigated crop in field OR9), and the mean population of $X$. campestris pv. carotae on the plants that tested positive ranged from $1.6 \times 10^{3}$ to 3.9 $\times 10^{7} \mathrm{CFU} / \mathrm{g}$ tissue (Fig. 4A). In contrast, $X$. campestris pv. carotae was only detected on one plant in one field in Washington during the second sampling period (the furrow irrigated crop in field WA8) (Fig. 3B) at $2.5 \times 10^{2} \mathrm{CFU} / \mathrm{g}$ tissue (Fig. 4B). None of the crops in Washington displayed symptoms of bacterial blight.

By April 2002, X. campestris pv. carotae was detected in 9 of 12 crops sampled in Oregon (all 8 direct-seeded crops and 1 of 4 steckling crops), at incidences ranging from 2 out of 20 plants ( $10 \%$ in fields OR4 and OR12) to 11 out of 20 plants (55\% in field OR7) (Fig. 3A), with a mean population ranging from $3.2 \times 10^{5}$ (field OR12) to $1.6 \times 10^{8} \mathrm{CFU} / \mathrm{g}$ tissue (field OR5) for plants that tested positive (Fig. 4A). Symptoms of bacterial blight were observed at a low incidence $(<10 \%)$ in a few crops in Oregon. In Washington, X. campestris pv. carotae was detected in 3 of 12 seed crops, at incidences ranging from 1 out of 20 plants $(5 \%)$ from the direct-seeded crops in each of fields WA4 and WA7, to 3 out of 20 plants (15\%) from the steckling crop in field WA13 (Fig. 3B). The stecklings for field WA13 were sampled directly out of the crates shipped from the Imperial Valley, CA. The population of $X$. campestris pv. carotae detected in Washington during this sampling period ranged from $2.5 \times 10^{7}$ to $5.0 \times 10^{8} \mathrm{CFU} / \mathrm{g}$ tissue (Fig. $4 \mathrm{~B}$ ) for those plants that tested positive, although none showed symptoms of bacterial blight.

By early June 2002, X. campestris pv. carotae was detected in all seed crops sampled in Oregon except the crop in field OR14 (Fig. 3A). The incidence of the pathogen detected in the other 11 crops ranged from 2 out of 20 plants $(10 \%$ in fields OR12 and OR13) to 18 out of 20 plants (90\% in field OR5), with a mean population ranging from $2.0 \times 10^{5}$ to $2.0 \times$ $10^{8} \mathrm{CFU} / \mathrm{g}$ tissue (Fig. 4A). Symptoms of bacterial blight were evident in most crops sampled in Oregon. In Washington, $X$. campestris pv. carotae was detected in 5 of 12 seed crops sampled, at incidences ranging from 1 out of 20 plants (5\% in fields WA5 and WA11) to 5 out of 20 plants 
(25\% in field WA12) (Fig. 3B), and a mean population ranging from $1.6 \times 10^{4}$ to $7.9 \times$ $10^{5} \mathrm{CFU} / \mathrm{g}$ tissue for those plants that tested positive (Fig. 4B). The pathogen was not detected in either of the steckling crops (fields WA13 and WA14), and none of the plants sampled in Washington showed symptoms of bacterial blight.

In August 2002, X. campestris pv. carotae was detected in all 10 crops sampled in central Oregon, at incidences ranging from 3 out of 20 plants (15\% in field OR13) to 20 out of 20 plants $(100 \%$ in fields OR2 and OR6) (Fig. 3A), and at a mean population ranging from $1.0 \times 10^{4}$ (field OR13) to $2.5 \times 10^{8} \mathrm{CFU} / \mathrm{g}$ tissue (fields OR5 to OR7) for the plants that tested positive (Fig. 4A). Similarly, the incidence of plants on which $X$. campestris pv. carotae was detected in Washington increased from June to late July 2002, when the pathogen was found in 11 of 12 crops (all except field WA14), at incidences ranging from 2 out of 20 plants $(10 \%)$ in field WA13 to 20 out of 20 plants $(100 \%)$ in field WA4 (Fig. 3B), with a mean population ranging from 6.3 $\times 10^{2}$ (field WA10) to $1.6 \times 10^{7} \mathrm{CFU} / \mathrm{g}$ tissue (field WA12) for plants that tested positive (Fig. 4B).
The mean incidence of plants that tested positive for $X$. campestris pv. carotae was usually greater in direct-seeded crops than in steckling crops. The average incidence of plants that tested positive for $X$. campestris pv. carotae by midsummer (July and August 2002) was 17 out of 20 plants $(85 \pm 20 \%)$ and 12 out of 20 plants $(59 \pm 26 \%)$ for the direct-seeded crops in Oregon and Washington, respectively, compared with 7 out of 20 plants $(35 \pm 31 \%)$ and 1 out of 20 plants ( 5 $\pm 7 \%$ ) for steckling crops in Oregon and Washington, respectively (Table 3 ).

2002-03 survey. Development of $X$. campestris pv. carotae followed a similar pattern in the crops surveyed in 2002-03 as observed in the 2001-02 survey. However, the pathogen was more prevalent in both states in early fall (October) of 2002 compared with 2001. In Oregon, only two of seven direct-seeded crops sampled in October 2002 tested free of X. campestris pv. carotae (the furrow irrigated crop in field OR16 and the overhead irrigated crop in field OR18). For the five crops in which the pathogen was detected, the incidence of infected plants ranged from 1 out of 20 plants $(5 \%$ in fields OR17, OR19, and OR20) to 2 out of 20 plants (10\% in fields OR15 and OR21) (Fig. 3C), with mean populations ranging from $7.9 \times 10^{4}$ (field OR21) to $1.6 \times 10^{6} \mathrm{CFU} / \mathrm{g}$ (field OR20) for plants that tested positive (Fig. 4C). By November 2002, X. campestris pv. carotae was detected on only 1 of 20 plants in each of six of the seven direct-seeded crops in Oregon (Fig. 3C), but at mean populations ranging from $1.6 \times 10^{3}$ (field OR17) to 2.5 $\times 10^{8} \mathrm{CFU} / \mathrm{g}$ (field OR15) (Fig. 4C). In Washington, X. campestris pv. carotae was detected in five of seven direct-seeded crops sampled in October 2002 prior to the onset of fall frosts, at incidences ranging from 1 out of 20 plants (field WA15) to 9 out of 20 plants (field WA18) (Fig. 3D), and mean populations of $6.3 \times 10^{3}$ (field WA18) to $1.0 \times 10^{5} \mathrm{CFU} / \mathrm{g}$ (field WA17) for those plants on which the pathogen was detected (Fig. 4D). By November 2002, the bacterium was found in only three of seven direct-seeded crops sampled in Washington, at incidences ranging from 1 (field WA16) to 4 (field WA15) out of 20 plants (Fig. 3D), and at mean populations of $3.2 \times 10^{3}$ to $6.3 \times 10^{4} \mathrm{CFU} / \mathrm{g}$ for plants that tested positive for $X$. campestris pv. carotae (Fig. 4D). None of the crops surveyed in Oregon or Washington in October and November 2002 showed symptoms of bacterial blight.
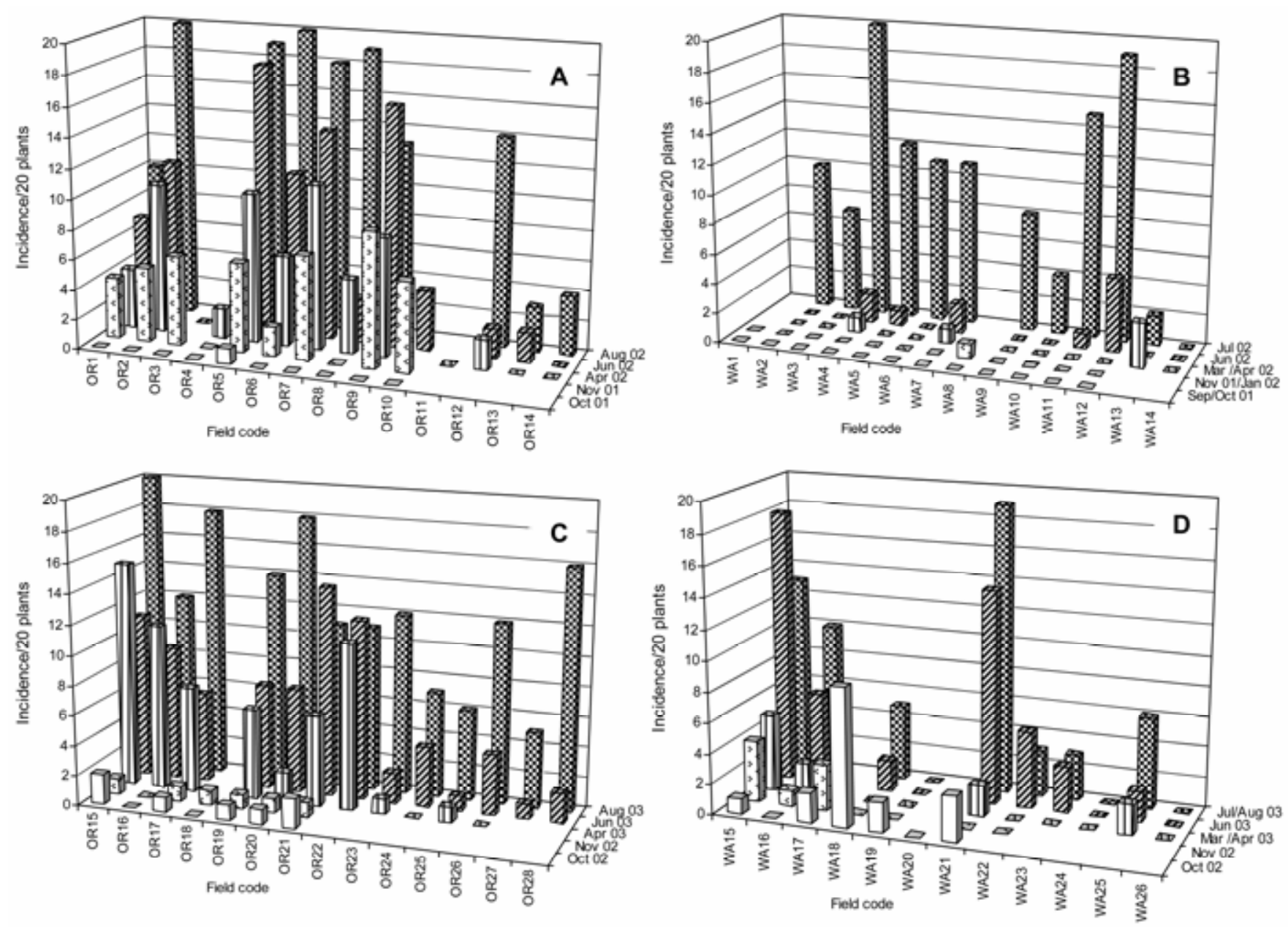

Fig. 3. Incidence of 20 plants from which Xanthomonas campestris pv. carotae was isolated in carrot seed crops sampled in Oregon and Washington in 2001-02 (A and B, respectively) and 2002-03 (C and D, respectively). 
By April 2003, only one of seven directseeded crops (field OR24) and one of five steckling crops (field OR26) sampled in Oregon tested free of $X$. campestris pv. carotae. For the six direct-seeded crops and three steckling crops in which the pathogen was detected, the incidence of infected plants ranged from 1 out of 20 plants (5\% in fields OR23 and OR25) to 15 out of 20 plants (75\% in field OR15) (Fig. 3C), with mean populations ranging from $4.0 \times 10^{4}$ (field OR20) to $1.3 \times 10^{8}$ CFU/g (field OR25) for plants that tested positive (Fig. 4C). In contrast, by March and April 2003, X. campestris pv. carotae was only detected in three of six directseeded crops and one of four steckling crops in Washington, at incidences ranging from 2 out of 20 plants (10\% in fields WA16, WA21, and WA25) to 5 out of 20 plants (field WA15) (Fig. 3D). For field WA25, the pathogen was detected on 2 of 10 male stecklings and 0 of 10 female stecklings sampled directly from the shipping crates. For plants that tested positive for $X$. campestris pv. carotae, the mean population of the pathogen ranged from $2.5 \times 10^{3}$ (steckling crop in field WA25) to $1.3 \times 10^{7} \mathrm{CFU} / \mathrm{g}$ (field WA15) (Fig. 4D).
The prevalence of $X$. campestris pv. carotae increased through the summer of 2003 in both Oregon and Washington. For the June and July-August sampling periods, the pathogen was detected in every direct-seeded and steckling crop sampled in Oregon, and in five of six direct-seeded crops and two of four steckling crops sampled in Washington (Fig. 3C and D). For the crops in which $X$. campestris pv. carotae was detected in June 2003, the incidence of infected plants ranged from 1 out of 20 plants (5\% in fields OR25 and OR27) to 14 out of 20 plants $(70 \%$ in field OR21) in Oregon, and from 2 out of 20 plants $(10 \%$ in fields WA18 and WA25) to 18 out of 20 plants $(90 \%$ in field WA15) in Washington (Fig. 3C and D). The mean population of $X$. campestris pv. carotae on plants that tested positive ranged from $1.6 \times 10^{4}$ (field OR24) to 1.3 $\times 10^{8} \mathrm{CFU} / \mathrm{g}$ (field OR24) in Oregon, and from $2.0 \times 10^{4}$ (field WA25) to $3.2 \times 10^{7}$ $\mathrm{CFU} / \mathrm{g}$ (field WA15) in Washington (Fig. 4C and D). By July-August 2003, the incidence of infected plants ranged from 5 out of 20 plants ( $25 \%$ in field OR27) to 20 out of 20 plants (100\% in field OR21) in Oregon, and from 3 out of 20 plants
(15\% in fields WA22 and WA23) to 19 out of 20 plants (95\% in field WA21) in Washington (Fig. 3C and D). The mean population of $X$. campestris pv. carotae on plants that tested positive ranged from $1.3 \times 10^{5}$ (field OR27) to $1.3 \times 10^{8}$ CFU/g (field OR21) in Oregon, and from $1.6 \times 10^{3}$ (field WA22) to $2.0 \times 10^{8}$ CFU/g (field WA21) in Washington (Fig. 4C and D). The Washington crops from which the pathogen was not detected in 2003 included a furrow irrigated seed crop in each of fields WA19 and WA24, and a drip irrigated organic seed crop in field WA26.

As in 2001-02, the mean incidence of plants that tested positive for X. campestris pv. carotae in the spring and summer of 2002-03 was typically higher for directseeded crops than for steckling crops. By July and August 2003, the mean incidence of plants that tested positive for the pathogen was 14 out of $20(69 \pm 21 \%)$ and 8 out of 20 plants $(42 \pm 35 \%)$ for direct-seeded crops in Oregon and Washington, respectively, compared with 10 out of $20(49 \pm$ $26 \%)$ and 2 out of 20 plants $(12 \pm 15 \%)$ for steckling crops in Oregon and Washington, respectively (Table 3 ).
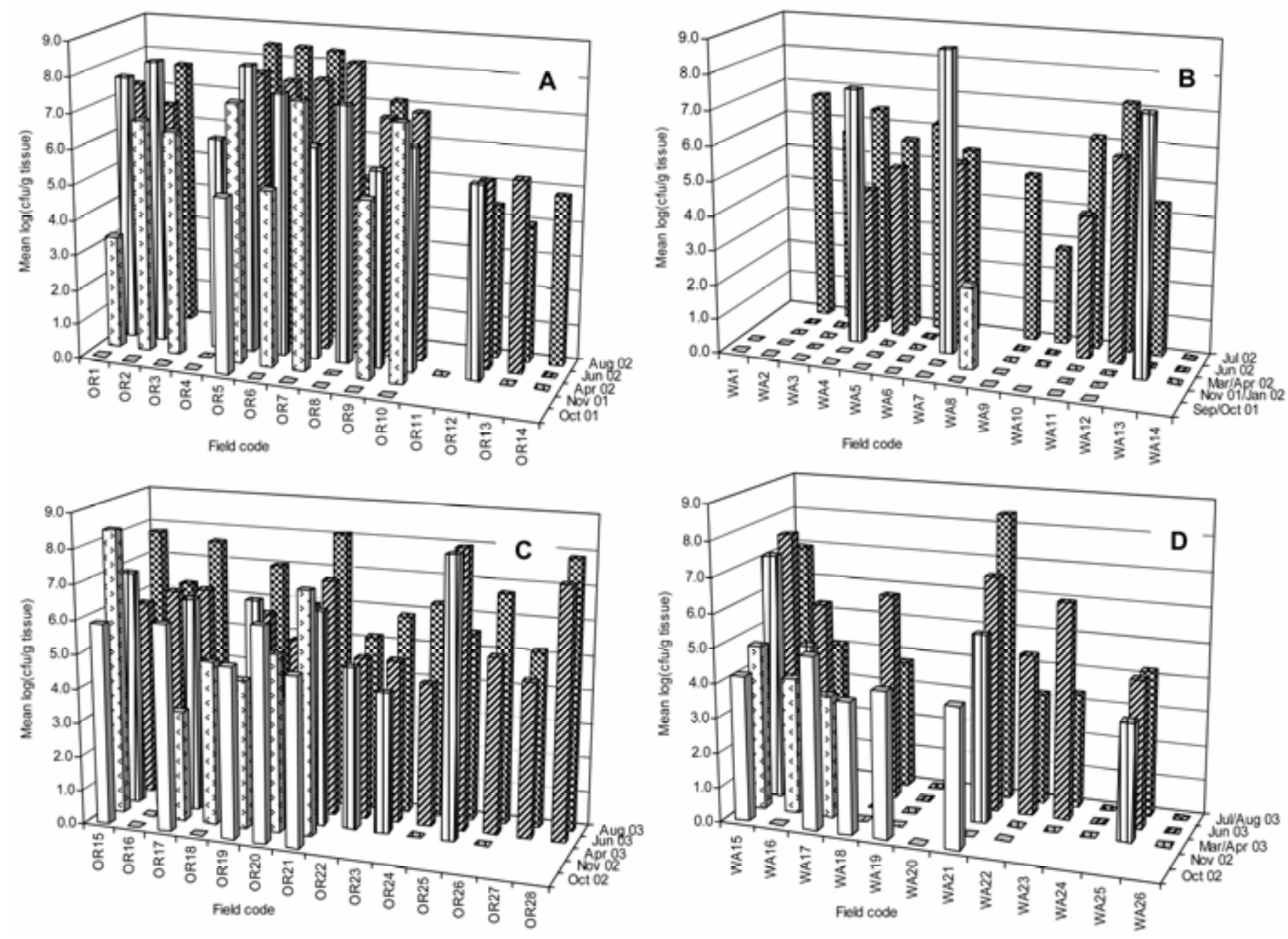

Fig. 4. Mean population of Xanthomonas campestris pv. carotae (log CFU/g dry plant tissue) detected on plants from which the pathogen was isolated in carrot seed crops sampled in Oregon and Washington in 2001-02 (A and B, respectively) and 2002-03 (C and D, respectively). 
2001-02 seed assays. Stock seed lots were not available for any of the steckling crops surveyed in Washington and Oregon in 2001-02. Similarly, stock seed was not available to assay for the open pollinated crop in field WA12, the female stock seed of the direct-seeded hybrid crops in fields OR1 to OR3 and OR5 to OR10, and the male stock seed of the direct-seeded hybrid crop in field OR4. None of the seven stock seed samples assayed in Oregon for the 2001-02 season tested positive for $X$. campestris pv. carotae (Fig. 5A). However, the pathogen was detected in stock seed samples for 4 of 11 carrot seed crops surveyed in central Washington in 2001-02, including the stock seed of the open pollinated seed crops in fields WA1, WA5, and WA6, and the male stock seed of the hybrid crop in WA11 (Fig. 5B). The mean population of $X$. campestris pv. carotae in these infected seed lots ranged from $<10$ $\mathrm{CFU} / \mathrm{g}$ seed for fields WA5 and WA6 to $2.1 \times 10^{5} \mathrm{CFU} / \mathrm{g}$ seed for field WA1.

$X$. campestris pv. carotae was detected in all 10 seed lots harvested from the Oregon seed crops surveyed in 2001-02, at populations ranging from $7.8 \times 10^{3} \mathrm{CFU} / \mathrm{g}$ seed for the overhead irrigated steckling crop in field OR12 to $3.5 \times 10^{7} \mathrm{CFU} / \mathrm{g}$ seed for the overhead irrigated directseeded crop in field OR6 (Fig. 5A). For seed lots harvested from crops surveyed in Washington in 2001-02, X. campestris pv. carotae was detected in 9 of 10 and 1 of 2 lots from the direct-seeded and steckling crops, respectively (Fig. 5B). The mean population of the pathogen detected in these infected lots ranged from $1.0 \times 10^{3}$ $\mathrm{CFU} / \mathrm{g}$ for the furrow irrigated directseeded crop in field WA9 to $3.5 \times 10^{7}$ $\mathrm{CFU} / \mathrm{g}$ seed for the furrow irrigated directseeded crop in field WA4. The pathogen was not detected in seed harvested from the furrow irrigated steckling crop in field WA13 even though the pathogen was found on stecklings for this crop in April 2002 (Fig. 3B). The harvested seed from 9 of 10 direct-seeded crops and 1 of 2 steckling crops sampled in Washington tested positive for $X$. campestris pv. carotae. Only the drip irrigated direct-seeded crop in field WA10 and the furrow irrigated steckling crop in field WA13 tested negative for the pathogen (Fig. 5B).

2002-03 seed assays. Only one of eight stock seed lots assayed for the carrot seed crops surveyed in Oregon in 2002-03 tested positive for $X$. campestris pv. carotae, at a mean population of $6.3 \mathrm{CFU} / \mathrm{g}$ seed (Fig. 5C). Similarly, only 2 of 16 stock seed lots assayed for the seed crops surveyed in Washington in 2002-03 tested positive for $X$. campestris pv. carotae $(=2$ infected stock seed lots for 9 seed crops, given 6 were hybrid crops with male and female stock seed lots), at a mean population of 25 and $72 \mathrm{CFU} / \mathrm{g}$ seed for fields WA25 (overhead irrigated) and WA24 (furrow irrigated), respectively (Fig. 5D).
In contrast, 10 of 12 seed lots harvested from the seed crops surveyed in Oregon in 2002-03 tested positive for the pathogen, at mean populations ranging from $\leq 2.0 \times$ $10^{2} \mathrm{CFU} / \mathrm{g}$ seed for the furrow irrigated crop in field OR23 and the overhead irrigated crop in field OR20, to $>10^{7} \mathrm{CFU} / \mathrm{g}$ seed for the overhead irrigated crops in fields OR15, OR19, OR21, and OR25 (Fig. 5C). For the crops surveyed in Washington in 2002-03, the harvested seed from 9 of 11 crops tested positive for $X$. campestris pv. carotae, at mean populations ranging from $9.3 \mathrm{CFU} / \mathrm{g}$ seed for the furrow irrigated crop in field WA24 to 4.7 $\times 10^{7} \mathrm{CFU} / \mathrm{g}$ seed for the overhead irrigated crop in field WA21 (Fig. 5D). The pathogen was not detected in the harvested seed from the furrow irrigated directseeded crop in field WA19, nor from the drip irrigated steckling seed crop in field WA26 (Fig. 5D). The latter crop was the only certified organic carrot seed crop in the survey.

Pathogenicity tests. All bacterial isolates that formed colonies characteristic of $X$. campestris on XCS and YDC agar, and for which the $3 \mathrm{~S}$ primer pair specific for $X$. campestris pv. carotae amplified a 350-bp fragment of genomic DNA by PCR assay, also proved pathogenic on carrot plants in the greenhouse. A few isolates $(<2 \%)$ that resembled $X$. campestris on XCS and YDC agar, but which did not test positive for $X$. campestris pv. carotae using the PCR assay, were not pathogenic when inoculated onto carrot seedlings. Colonies of these isolates were typically observed in low numbers $(<25 \mathrm{CFU} / \mathrm{g})$ on XCS plates after plating the dilution series from foliage and seed washes.

Table 3. Mean \pm standard deviation of the incidence (\%) of plants on which Xanthomonas campestris pv. carotae was detected in direct-seeded and steckling carrot seed crops sampled in 2001-02 and 2002-03 in central Oregon and central Washington

\begin{tabular}{lccccc}
\hline \multirow{2}{*}{$\begin{array}{c}\text { Season, state, and } \\
\text { planting method }\end{array}$} & \multicolumn{5}{c}{ Sampling period $^{\mathbf{b}}$} \\
\cline { 2 - 6 } & Sept-Oct & Nov-Jan & March-April & June & July-Aug \\
\hline $\begin{array}{c}\text { 2001-02 } \\
\text { Oregon }\end{array}$ & & & & \\
$\quad$ Direct-seeded & $0.5 \pm 1.5$ & $22.5 \pm 15.0$ & $35.0 \pm 16.5$ & $42.0 \pm 33.0$ & $85.0 \pm 19.5$ \\
$\quad$ Steckling & - & - & $2.5 \pm 5.0$ & $6.5 \pm 6.0$ & $35.0 \pm 30.5$ \\
Washington & & & & & \\
$\quad \begin{array}{l}\text { Direct-seeded } \\
\text { Steckling }\end{array}$ & 0.0 & $0.5 \pm 1.5$ & $1.0 \pm 2.0$ & $5.5 \pm 8.0$ & $58.5 \pm 25.5$ \\
2002-03 & - & - & $7.5 \pm 10.5$ & 0.0 & $5.0 \pm 7.0$ \\
Oregon & & & & & \\
Direct-seeded & $5.0 \pm 4.0$ & $4.5 \pm 2.0$ & $33.0 \pm 25.5$ & $40.0 \pm 19.5$ & $68.5 \pm 21.0$ \\
$\quad$ Steckling & - & - & $2.5 \pm 3.5$ & $10.0 \pm 7.0$ & $49.0 \pm 26.0$ \\
Washington & & & & & \\
$\quad$ Direct-seeded & $12.0 \pm 15.5$ & $5.5 \pm 8.5$ & $7.5 \pm 10.0$ & $37.5 \pm 35.0$ & $41.5 \pm 35.0$ \\
Steckling & - & - & $2.5 \pm 5.0$ & $6.5 \pm 7.5$ & $11.5 \pm 14.5$ \\
\hline
\end{tabular}

${ }^{a}$ Direct-seeded crops were planted in August or early September each season. For steckling crops, seed was sown in September in Imperial Valley, CA, or Yuma, AZ. Roots were dug in January or February, placed in cold storage for 6 to 8 weeks, transported to the Pacific Northwest, and transplanted. In Oregon, 7 to 10 direct-seeded crops and 3 to 4 steckling crops were sampled at each period in 2001-02; and 6 to 7 direct-seeded crops and 5 to 7 steckling crops were sampled in 200203. In Washington, 10 to 12 direct-seeded crops and 2 steckling crops were sampled at each period in 2001-02; and 6 to 7 direct-seeded crops and 4 steckling crops were sampled in 2002-03.

${ }^{\mathrm{b}}$ Twenty plants per field were assayed for $X$. campestris pv. carotae at each sampling period using a foliar wash and dilution plating method onto XCS agar medium as described by Umesh et al. (31) and Meng et al. (17).
Sampling of dust and debris during
threshing of carrot seed crops. $X$. campestris pv. carotae was detected in airborne dust and debris downwind of seed 2). The population of $X$. campestris pv. carotae detected varied depending on wind ranged from a mean of 1 to $954 \mathrm{CFU} /$ liter air. In general, the airborne population of distance from the thresher. However, the thogen was detected approximately 1.6 site 4 , which was also located within 2.5 to $\mathrm{km}$ of at least five other seed crops of seed harvested from three of the six all tested positive for the patho$10^{5}$ to $9.9 \times 10^{7} \mathrm{CFU} / \mathrm{g}$ seed (Table 2).

Sampling of honey bees. $X$. campestris pv. carotae was not isolated from any of in July 2003. Similarly, the bacterium was not detected on 100 honey bees sampled located near Yakima, WA, in July 2004 that displayed a low incidence of symptoms of campestris pv. carotae was isolated at an each containing 5 bees collected from the hybrid seed crop located near Madras, OR, symptoms of bacterial blight. Similarly, bacterium was detected at a mean tubes $(5 \%)$ each containing 5 bees from the hybrid seed crop near Culver, OR, in average population of $47 \mathrm{CFU} / \mathrm{ml}$ phos- 
which 5 to $10 \%$ of the plants had symptoms of bacterial blight. However, for all three seed crops from which bees were sampled in 2004, X. campestris pv. carotae was not isolated from either of the two control (spiked) test tubes, i.e., neither from the phosphate buffer containing five honey bees to which $X$. campestris pv. carotae was added, nor from phosphate buffer alone to which the bacterium was added. Furthermore, the phosphate buffer in most of the centrifuge tubes (including those that tested positive for $X$. campestris pv. carotae) also contained pieces of stamens and petals inadvertently picked up while collecting the bees. This flower tissue may have been contaminated with $X$. campestris pv. carotae.

Environmental conditions and cultural practices. Daily minimum and maximum temperatures were similar for Madras, OR, and Moses Lake, WA, from 1 August 2001 to 30 September 2003. Over the duration of this survey, the lowest tem- perature was recorded on 31 October 2002 in Madras $\left(-15.7^{\circ} \mathrm{C}\right)$ and Moses Lake $\left(-13.7^{\circ} \mathrm{C}\right)$, and the highest temperature occurred on 12 July 2002 in Madras $\left(39.6^{\circ} \mathrm{C}\right)$ and Moses Lake $\left(40.7^{\circ} \mathrm{C}\right)$. However, total heat units over the duration of this study measured $2,866^{\circ} \mathrm{C}$ for Madras versus $3,550^{\circ} \mathrm{C}$ for Moses Lake. The numbers of heat units measured from 1 October to 31 December 2001, 1 January to 31 December 2002, and 1 January to 30 September 2003 were 17, 28, and 23\% greater in Moses Lake than Madras, respectively. Similarly, Madras experienced 78 days with the average temperature below freezing $\left(<0^{\circ} \mathrm{C}\right)$ versus 69 days for Moses Lake. Total precipitation from 1 August 2001 to 30 September 2003 measured $223 \mathrm{~cm}^{3}$ in Madras versus $259 \mathrm{~cm}^{3}$ in Moses Lake. In the fall of 2001 (1 August to 31 December 2001), more precipitation was recorded in Madras $\left(67 \mathrm{~cm}^{3}\right)$ than in Moses Lake (55 $\mathrm{cm}^{3}$ ). Similar levels of total precipitation were measured in both regions in 2002 $\left(108 \mathrm{~cm}^{3}\right.$ in Madras and $115 \mathrm{~cm}^{3}$ in Moses Lake), but Madras received significantly less precipitation than Moses Lake from 1 January to 30 September 2003 (48 versus $89 \mathrm{~cm}^{3}$, respectively).

Based on information available from seed companies, two to three copper applications were made in the fall of both seasons in a majority of the carrot seed crops surveyed in central Oregon for management of bacterial blight, but fall copper applications were not made in any of the seed crops surveyed in central Washington in either season. In addition, most seed crops in Oregon and a few seed crops in Washington received one to three copper bactericide applications in late spring and/or summer. Carrot seed growers typically use a minimum of 5 years of rotation between carrot seed crops in each state.

\section{DISCUSSION}

$X$. campestris pv. carotae was detected in a majority of the carrot seed crops sur-
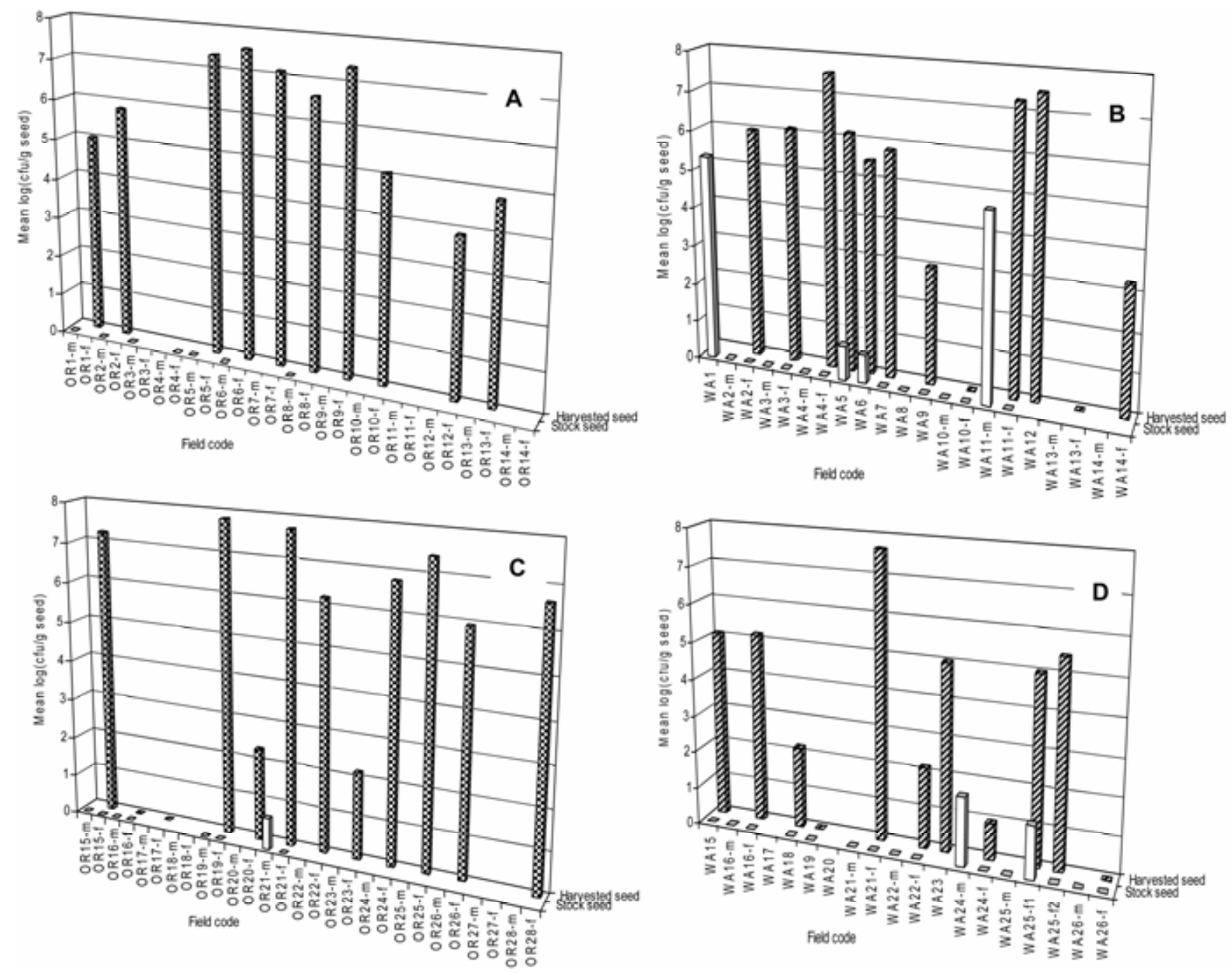

Fig. 5. Mean population of Xanthomonas campestris pv. carotae (log CFU/g seed) detected in stock seed and harvested seed samples from carrot seed crops grown in Oregon and Washington in 2001-02 (A and B, respectively) and 2002-03 (C and D, respectively). Missing bars indicate seed samples were not provided by the seed company. For stock seed lots, "f" and "m" indicate seed of the female and male parent lines, respectively; and "f1" and "f2" indicate seed of two different female parent lines planted in the same crop. For hybrid seed crops, harvested seed lots represent seed harvested from the female line. Data are means of three 10-g seed samples per lot, assayed by dilution plating a seed wash onto XCS agar (17,31). 
veyed in the semi-arid region of central Oregon and central Washington in 200102 and 2002-03, including direct-seeded and steckling crops. The pathogen was detected as early as 1 to 2 months after planting, but symptoms were not observed in any of the crops at both the early (prefrost) and late (after the start of frosts) fall sampling periods each season. Populations of $X$. campestris pv. carotae detected in the fall of each season were typically $<10^{5}$ $\mathrm{CFU} / \mathrm{g}$ tissue, but increased with subsequent spring (March to April), early summer (June), and mid-summer (July to August) sampling periods. Symptoms of bacterial blight were first observed in Oregon in spring (April) and in Washington in summer (July), by which time the pathogen was detected at populations $>10^{6}$ to $10^{8} \mathrm{CFU} / \mathrm{g}$ foliage. These results corroborate the statement by Gilbertson (8) that symptoms of bacterial leaf blight only develop when epiphytic populations of the pathogen reach $>10^{6} \mathrm{CFU} / \mathrm{g}$ leaf tissue.

Sources of inoculum of $X$. campestris pv. carotae detected in this study included infested stock seed lots, infected stecklings, and aerosolized bacteria associated with infested carrot debris or dust particles generated during the seed threshing process after crops had been windrowed and dried in late summer or early fall. Samples of stock seed lots were only available to assay for 31 of the 52 seed crops monitored in this study. Nonetheless, the limited number of stock seed lots that tested positive for $X$. campestris pv. carotae compared with the prevalence of the pathogen in the crops surveyed suggests infested stock seed may not be the most significant source of inoculum in this region of carrot seed production. Of 47 stock seed lots assayed using a seed wash and dilution plating protocol with a detection limit of one naturally infested seed in 10,000 (15), only seven lots $(15 \%)$ were infested with $X$. campestris pv. carotae, representing $23 \%$ of the planting material for 31 crops. Furthermore, the population of $X$. campestris pv. carotae detected in these seven stock seed lots was $<10^{2} \mathrm{CFU} / \mathrm{g}$ seed for five lots, and $6.6 \times 10^{4}$ and $2.0 \times 10^{5}$ $\mathrm{CFU} / \mathrm{g}$ seed for the other two lots. Umesh et al. (31) demonstrated that under the semi-arid conditions of central California, the threshold of carrot seed contamination by $X$. campestris pv. carotae for establishment of the pathogen on leaves and for development of bacterial blight in a carrot crop grown under overhead (sprinkler) irrigation was "unexpectedly high", i.e., $10^{4}$ to $10^{5} \mathrm{CFU} / \mathrm{g}$ seed. To our knowledge, similar studies evaluating thresholds for seedborne inoculum in carrot seed crops have not been carried out. If a comparable threshold exists for carrot seed crops in the similarly semi-arid conditions of central Oregon and central Washington, only two of the seven infested stock seed lots detected in this survey would have resulted in establishment of the pathogen on the seed crop. Both of the crops planted with these infested stock seed lots were grown using overhead irrigation, which promotes dispersal of the pathogen in splashing water (8). One of the two crops (WA1) was abandoned in spring 2002 because the seed company no longer needed the seed, but seed harvested from the other crop (WA11) had a high level of $X$. campestris pv. carotae ( $>10^{7} \mathrm{CFU} / \mathrm{g}$ seed).

$X$. campestris pv. carotae was isolated from carrot stecklings sampled directly out of the shipping crates for 4 of 12 steckling crops surveyed (33\%), demonstrating that infected stecklings may provide a source of inoculum for carrot seed crops in the Pacific Northwest. Detection of the pathogen on stecklings prior to transplanting emphasizes the importance of producing stecklings in regions where bacterial blight is not endemic, and/or treating stecklings prior to transplanting using chlorine. Kendrick (13) similarly reported the association of infected stecklings with outbreaks of bacterial blight in carrot seed crops in the Sacramento Valley of California from 1931 to 1933. Despite detection of the pathogen on stecklings prior to transplanting, the incidence and population of $X$. campestris pv. carotae were generally lower in steckling crops than in directseeded crops in this study.

To prevent pollen contamination and ensure genetic purity of the harvested seed, carrot seed crops are separated spatially by distances ranging from $0.4 \mathrm{~km}$ (between closely related cultivars) to $>3.0 \mathrm{~km}$ (between hybrid crops and between hybrid and open pollinated seed crops of different cultivars) (3). This spatial isolation of individual crops within seasons provides some control of bacterial blight by minimizing dispersal of the pathogen between crops. However, airborne $X$. campestris pv. carotae was detected up to $2.5 \mathrm{~km}$ downwind of seed crops being threshed, indicating that inoculum can be dispersed greater distances than the pollen isolation distances adhered to by seed growers in the Pacific Northwest. Such aerial dispersal of bacteria has been reported to play a role in development of a number of other bacterial plant pathogens $(9,16,27,32)$. In addition, because of the overlap in consecutive biennial seasons, carrot seed crops in the Pacific Northwest are often seeded in close proximity to mature seed crops from the previous season, creating a "green bridge" between seasons. The availability of fewer irrigated acres in central Oregon than in central Washington has resulted in more carrot seed crops being planted in close proximity to mature crops of the previous season in Oregon than in Washington. Furthermore, direct-seeded crops are typically planted 3 to 5 weeks earlier in Oregon than in Washington, resulting in a longer green bridge effect in Oregon. Carrot seedlings are more likely to have emerged in Oregon than in Washington at the time crops of the previous season are harvested, potentially exposing young susceptible carrot leaves to windblown infested debris. This may account, in part, for the greater prevalence of $X$. campestris pv. carotae detected in carrot seed crops in Oregon than in Washington, both in terms of the incidence of plants on which $X$. campestris pv. carotae was detected and the population of the pathogen on those plants. This green bridge effect is compounded by the location of annual carrot crops within the same region as carrot seed crops, particularly in central Washington, which ranks first in the United States for production of processing carrots (approximately 2,600 ha) and fourth for fresh market carrots (approximately 1,200 ha) (26).

The potential role of honey bee pollinators as vectors of $X$. campestris pv. carotae in carrot seed crops was not clarified in this study. Although the pathogen was detected in the phosphate wash from honey bees foraging in each of two symptomatic carrot seed crops in Oregon in 2004, the bee wash that tested positive for the pathogen also contained flower parts that may have been infected with $X$. campestris pv. carotae, confounding the ability to determine if honey bees inadvertently disperse the pathogen during flowering and seed set. Also, the pathogen was not detected in the phosphate buffer spiked with the bacterium, suggesting problems with the technique used in this study. Further investigation of the potential role of honey bees in development of bacterial blight in carrot seed crops is warranted, given that bees are known to serve as vectors of other bacterial plant pathogens (2).

Splashing water from overhead irrigation or precipitation may disperse $X$. campestris pv. carotae to adjacent plants from infected stecklings or seedlings. Furthermore, overhead irrigation creates favorable (humid) microclimates for development of $X$. campestris pv. carotae (8). Results from crops surveyed in Washington in this study support the recommendation to use furrow or drip irrigation to minimize development of bacterial blight, as harvested seed lots that tested negative for the pathogen in Washington were all grown using drip or furrow irrigation. In contrast, in Oregon in 2001-02, there was little evidence of a greater increase in populations of $X$. campestris pv. carotae in carrot seed crops produced with overhead irrigation versus furrow irrigation. Similarly, of the two crops for which harvested seed tested negative for the pathogen in Oregon in 2002-03, one was grown using furrow irrigation and the other with overhead irrigation. The difference in prevalence of X. campestris pv. carotae in overhead versus furrow irrigated crops in Oregon compared with Washington may be the result of more prevalent inoculum in Oregon than Washington (e.g., from in- 
fested windblown carrot residues during seed threshing). Furthermore, some directseeded crops grown in Oregon using furrow irrigation are initially irrigated with sprinkler systems in the fall to facilitate rapid and uniform seed germination and seedling emergence. The growers then switch to furrow irrigation the following spring. In the presence of $X$. campestris pv. carotae from infested seed or windblown infested carrot residues, this practice may favor early establishment of the pathogen on carrot seedlings in direct-seeded crops. Preliminary research into the potential use of drip irrigation for management of bacterial blight in carrot seed crops demonstrated reduction in epiphytic populations of $X$. campestris pv. carotae on plants and reductions in populations of the pathogen on seed harvested from drip irrigated sections compared with overhead irrigated sections of each crop (F. Crowe and M. Butler, unpublished data). As a result, the acreage of carrot seed crops produced in central Oregon using drip irrigation has recently increased (34).

The optimal temperature range for infection of carrots by $X$. campestris pv. carotae is 25 to $30^{\circ} \mathrm{C}$, although infection can occur at higher temperatures $(13,20)$. While investigating seed contamination thresholds for bacterial blight in fresh market carrot production in central California in 1995 and 1996, Umesh et al. (31) suggested conditions were more favorable for bacterial blight in the 1996 trial than the 1995 trial, as temperatures typically ranged from 28 to $35^{\circ} \mathrm{C}$ during the 1996 trial but often reached $>40^{\circ} \mathrm{C}$ in the 1995 trial. Daily minimum and maximum temperatures were similar in central Oregon (represented by Madras) and central Washington (represented by Moses Lake) over the duration of the carrot seed crop survey. Temperatures from 25 to $30^{\circ} \mathrm{C}$ occurred regularly from June through August of each season in both states, coinciding with the period of most rapid increase in incidence and population of $X$. campestris pv. carotae. However, considerably more heat units (17 to $28 \%$ ) were recorded in central Washington than in central Oregon each season, primarily during late spring and summer. The greater number of days with maximum temperatures above $30^{\circ} \mathrm{C}$ in Washington versus Oregon may have slowed development of the pathogen in seed crops in Washington compared with Oregon.

Detection of epiphytic populations of $X$. campestris pv. carotae within 2 months of planting carrot seed crops in the Pacific Northwest suggests fall applications of copper bactericides may delay development of bacterial blight. However, fall applications of copper sprays to carrot seed crops in Oregon, a practice seldom carried out in Washington (11), appears to have had limited efficacy against $X$. campestris pv. carotae. It is difficult to determine when to initiate copper applications for a disease for which symptoms only develop when the pathogen population is $>10^{6}$ CFU/g foliage (8). In this study, $X$. campestris pv. carotae was detected as early as 2 to 3 months after planting, but symptoms of bacterial blight were first observed about 8 months after planting (April) in Oregon and by 10 to 11 months after planting (June to July) in Washington. In field trials, du Toit and Derie (7) demonstrated significant reductions in populations of $X$. campestris pv. carotae on seed harvested from plots treated with copper hydroxide (Kocide 2000, DuPont Crop Protection, Wilmington, DE) or copper hydroxide-mancozeb (ManKocide DF, DuPont Crop Protection) once a month from May to August compared with nontreated control plots in a steckling seed crop trial. In the trial, copper applications were initiated prior to appearance of symptoms of bacterial blight. Chemigated applications of ManKocide DF through sprinklers significantly reduced populations of $X$. campestris pv. carotae on the harvested seed compared with four monthly boom applications of ManKocide DF, presumably because of improved coverage of the dense canopy when using chemigation versus boom spray applications. Although overhead irrigation systems may increase dispersal of the pathogen within seed crops compared with furrow and drip irrigated crops, these results indicate that more effective management of bacterial blight may be achieved by chemigated applications of copper bactericides than by spray boom applications.

The population of $X$. campestris pv. carotae detected on the harvested seed generally reflected incidence of the pathogen detected in seed crops in July and August. For example, the pathogen was not found in fields WA19, WA24, and WA26 in July and August 2003. The pathogen was not detected on the seed harvested from fields WA19 and WA26, and the seed harvested from field WA24 had the lowest population of $X$. campestris pv. carotae of the infected harvested seed lots. Of 44 harvested seed lots assayed from seed crops in Oregon and Washington over both seasons, 14 (32\%) were either not infested with $X$. campestris pv. carotae or were infested below $10^{4}$ to $10^{5} \mathrm{CFU} / \mathrm{g}$ seed, a threshold identified for the semi-arid region of central California (31). However, this threshold for seedborne inoculum may be lower in more humid regions of carrot production, such as the eastern and midwestern states of the United States. Research is needed to identify seed contamination thresholds for such regions. For seed lots exported to these regions of carrot production, hot water treatment can be used to eradicate the pathogen or reduce the level of contamination $(1,8)$. Hot water seed treatments are not used consistently by the carrot seed industry (28), as demonstrated by the infested stock seed lots detected in this study. Stock seed lots often are produced in different countries from where seed crops are grown, with inadequate time after release and shipment of the stock seed for seed treatment prior to the deadlines for planting biennial seed crops. In addition, the seed industry reports difficulties with maintaining precise water temperature and uniformity of heating when treating large volumes of seed, with potential for damaging seed germination if seed is not treated precisely and dried rapidly immediately after treatment (28). However, Strandberg and White (28) demonstrated that disease control benefits typically outweigh minor deleterious effects of hot water treatments on carrot seed performance.

A few isolates that resembled $X$. campestris pv. carotae on XCS agar did not test positive for this pathovar using the PCR assay. These isolates were not pathogenic when inoculated onto carrot seedlings, supporting the value of the PCR assay for confirming identification of isolates of $X$. campestris pv. carotae from carrot substrates (17). Using the seed wash protocol described above, the dilution plating assay proved more sensitive than the PCR assay carried out directly on the seed wash, and the dilution plating assay enabled the pathogen to be quantified from foliage and seed extracts. However, Meng et al. (17) demonstrated that problems with false negative results using the PCR assay directly on seed washes can be overcome by diluting the seed wash prior to carrying out the PCR assay in order to remove PCR inhibitors present in the seed extract.

Detection of $X$. campestris pv. carotae on stock seed and stecklings serves as a valuable reminder of the importance of starting with clean planting material, particularly for biennial seed crops in which the 13- to 14-month season provides an extended duration for dispersal and development of the pathogen. Seed harvested from the crop in field WA26 tested free of $X$. campestris pv. carotae. Stecklings for this certified organic seed crop were produced in a region of the Pacific Northwest isolated from other carrot seed and processing crops. Furthermore, the stock seed from which the stecklings were produced was treated with hot water to prevent planting material from serving as a source of inoculum. The stecklings were transplanted into a field located $>10$ miles from any other carrot seed or processing crop, and the crop was grown under drip irrigation to reduce the possibility of splash dispersal of inoculum. In addition, all six harvested seed lots that tested negative for $X$. campestris pv. carotae in this study were from crops planted with stock seed that tested negative for the bacterium, and five of the crops were grown using drip or overhead irrigation. Although this survey demonstrates that $X$. campestris pv. caro- 
tae is well established in the Pacific Northwest, the primary region of carrot seed production in the United States, the results also demonstrate that carrot seed free of $X$. campestris pv. carotae can be produced in this region by diligent adherence to cultural practices recommended for control of bacterial blight (8).

\section{ACKNOWLEDGMENTS}

We thank the California Fresh Carrot Advisory Board for funding this project; Mike Davis, Bob Gilbertson, Joe Nunez, and Shawn Meng for collaborative assistance; the Columbia Basin Vegetable Seed Association and carrot seed companies in Washington and Oregon for information on carrot seed production and for access to carrot seed crops and seed lots; and Louise Brissey, Bob Case, Brandi Jorgensen, Barbara Holmes, Raina Spence, Kari Berglund, Nathan Lloyd, Sarah Lloyd, Sam Sampson, and Kate Baber for technical assistance. This project was supported by the Agricultural Research Center at Washington State University, and is listed as Plant Pathology New Series no. 0395 .

\section{LITERATURE CITED}

1. Ark, P. A., and Gardner, M. W. 1944. Carrot bacterial blight as it affects the roots. Phytopathology 34:416-420.

2. Beer, S. V. 1990. Fire blight. Pages 61-63 in: Compendium of Apple and Pear Diseases. American Phytopathological Society, St. Paul, MN.

3. Columbia Basin Vegetable Seed Field Representatives Association. 2004. Columbia Basin Vegetable Seed Association Field Isolation Standards. Washington State University Extension, Ephrata.

4. Dellaporta, S. L., Woods, J., and Hicks, J. B. 1983. A plant DNA minipreparation: Version II. Plant Mol. Biol. Rep. 1:19-21.

5. du Toit, L. J., Crowe, F. J., Derie, M. L., Simmons, R. B., and Pelter, G. Q. 2004. Bacterial blight of carrot seed crops: Identification of sources of inoculum. Pages 27-41 in: 2003 Annual Report of the California Fresh Carrot Advisory Board, Dinuba, CA.

6. du Toit, L. J., Crowe, F. J., Derie, M. L., Simmons, R. B., and Pelter, G. Q. 2004. Bacterial blight of carrot seed crops in the Pacific Northwest. (Abstr.) Phytopathology 94:S26.

7. du Toit, L. J., and Derie, M. L. 2005. Evaluation of Actigard, bactericides, and compost teas for control of bacterial blight in carrot seed crops. Fungic. Nematicide Tests 60:V046. Published online.

8. Gilbertson, R. L. 2002. Bacterial leaf blight of carrot. Pages 11-12 in: Compendium of Umbelliferous Crop Diseases. American Phytopathological Society, St. Paul, MN.

9. Graham, D. C., and Harrison, M. D. 1975. Potential spread of Erwinia spp. in aerosols. Phytopathology 65:739-741.

10. Hart, J., and Butler, M. 2004. Hybrid Seed Carrot (Central Oregon). Nutrient Management Guide. Oregon State University EM 8879-E, Corvallis, OR

11. Hinman, H., and Pelter, G. Q. 1997. 1997 Enterprise budgets: Carrot seed, radish seed, and onion seed, Columbia Basin, WA. Washington State Univ. Ext. Bull. No. 1664. Pullman, WA.

12. Kado, E. I., and Heskett, M. G. 1970. Selective media for isolation of Agrobacterium, Corynebacterium, Erwinia, Pseudomonas, and Xanthomonas. Phytopathology 60:969-976.

13. Kendrick, J. B. 1934. Bacterial blight of carrot. J. Agric. Res. 49:493-510.

14. Kuan, T. L. 1989. Detection of Xanthomonas campestris pv. carotae in carrot. Pages 63-67 in: Detection of Bacteria in Seed and Other Planting Material. A. W. Saettler, N. W. Schaad, and D. A. Roth, eds. American Phytopathological Society, St. Paul, MN.

15. Kuan, T.-L., Minsavage, G. V., and Gabrielson, R. L. 1985. Detection of Xanthomonas campestris pv. carotae in carrot seed. Plant Dis. 69:758-760.

16. Kuan, T.-L., Minsavage, G. V., and Schaad, N. W. 1986. Aerial dispersal of Xanthomonas campestris pv. campestris from naturally infected Brassica campestris. Plant Dis. 70:409413.

17. Meng, X. Q., Umesh, K. C., Davis, R. M., and Gilbertson, R. L. 2004. Development of PCRbased assays for detecting Xanthomonas campestris pv. carotae, the carrot bacterial leaf blight pathogen, from different substrates. Plant Dis. 88:1226-1234.

18. Nishiyama, K., Fukunishi, T., Terada, T., and Ezuka, A. 1979. Bacterial blight of carrot Daucus carota var. sativa caused by Xanthomonas carotae a bacterial disease new to Japan. Ann. Phytopathol. Soc. Jpn. 45:683-688.

19. Pelter, G. Q. 2001. A Recent History of Columbia Basin Vegetable Seed Acreage: 19912000. Washington State University Extension, Grant-Adams Area, Ephrata.

20. Pfleger, F. L., Harman, G. E., and Marx, G. A. 1974. Bacterial blight of carrots: Interaction of temperature, light, and inoculation procedures on disease development of various carrot cultivars. Phytopathology 64:746-749.

21. Poplawsky, A. R., Robles, L., Chun, W., Derie, M. L., du Toit, L. J., Meng, X. Q., and Gilbertson, R. L. 2004. Identification of a Xanthomonas pathogen of coriander from Oregon
USA. (Abstr.) Phytopathology 94:S85.

22. Rubatzky, V. E., Quiros, C. F., and Simon, P. W. 1999. Carrots and Related Umbelliferae. Crop Production Science in Horticulture Series No. 10. CABI Publishing, New York.

23. Saad, S. M., and Wade, E. K. 1972. Bacterial blight of carrot in Wisconsin. Plant Dis. Rep. 56:744-746

24. Schaad, N. W., Jones, J. B., and Chun, W. 2001. Laboratory Guide for Identification of Plant Pathogenic Bacteria. 3rd ed. American Phytopathological Society, St. Paul, MN

25. Schreiber, A., and Ritchie, L. 1995. Washington Minor Crops. Food \& Environmental Quality Lab, Washington State University TriCities, Richland.

26. Sorensen, E. J. 2000. Crop Profile for Carrots in Washington. Washington State University, Pullman, WA, and U.S. Dep. Agric. National Pest Manage. Centers.

27. Southey, R. F. W., and Harper, G. J. 1971. The survival of Erwinia amylovora in airborne particles: Tests in the laboratory and in the open air. J. Appl. Bacteriol. 34:547-556.

28. Strandberg, J. O., and White, J. M. 1989 Response of carrot seeds to heat treatments. J. Am. Soc. Hortic. Sci. 114:766-769.

29. Thomas, J., Schreiber, A., Pelter, G. Q., and Havens, D. 1997. Washington's Small-Seeded Vegetable Seed Industry. Washington State University Ext. Bull. No. 1829.

30. Umesh, K. C., Davis, R. M., and Gilbertson, R. L. 1996. Seed contamination thresholds associated with occurrence of bacterial blight of carrots and development of a DNA based detection method for Xanthomonas campestris pv. carotae. (Abstr.) Phytopathology 86:S11.

31. Umesh, K. C., Davis, R. M., and Gilbertson, R. L. 1998. Seed contamination thresholds for development of carrot bacterial blight caused by Xanthomonas campestris pv. carotae. Plant Dis. 82:1271-1275.

32. Venette, J. R., and Kennedy, B. W. 1975. Naturally produced aerosols of Pseudomonas gly cinea. Phytopathology 65:737-738.

33. Watson, R. D. 1948. Carrot bacterial blight control in Idaho. Plant Dis. Rep. 32:238-239.

34. Weber, C. E., Butler, M. D., Campbell, C. K., Holliday, B. A., and Klauzer, J. 2004. Management Guide for Drip Irrigation on Seed Carrots in Central Oregon. Oregon State University EM 8880-E, Corvallis.

35. Williford, R. E., and Schaad, N. W. 1984. Agar medium for selective isolation of Xanthomonas campestris pv. carotae from carrot seeds. (Abstr.) Phytopathology 74:1142.

36. Zhang, Y.-P. 1996. Etiological study of cherry stem pitting disease and molecular characterization of sour cherry green ring mottle virus. $\mathrm{PhD}$ diss. University of California, Davis. 